\title{
A new species of Scaphyglottis (Orchidaceae, Epidendroideae) from Colombia
}

\author{
Dariusz L. Szlachetko • Marta Kolanowska
}

Received: 26 June 2013/ Accepted: 20 October 2013/Published online: 9 November 2013

(C) The Author(s) 2013. This article is published with open access at Springerlink.com

\begin{abstract}
A new species of Scaphyglottis from Colombia is described, illustrated and placed within the key for the determination of national Scaphyglottis species. Its taxonomic affinity is briefly discussed and the information about its distribution and ecology are provided.
\end{abstract}

Keywords Colombia $\cdot$ Orchids $\cdot$ New species .

Scaphyglottis · Taxonomy

\section{Introduction}

Since the description of Scaphyglottis in 1836 (Poeppig and Endlicher 1836), its infrageneric classification has been debated by taxonomists. The leaf blade and internode shapes, form of the lip and its fusion with the gynostemium, and number of pollinia were the principle characters considered as a basis for the delimitation of separate genera-Costaricaea Schltr., Hexisea Lindl., Platyglottis L.O. Williams, Reichenbachanthus Barb.Rodr., and Tetragamestus Rchb.f. Those taxa were accepted in various combinations by scientists. Ames (1937) recognized Reichenbachanthus and monotypic Costaricaea as synonyms of Hexisea, while Adams (1988) limited the latter genus to $H$. bidentata and $H$. imbricata. The recent molecular insight on the classification of Scaphyglottis (Dressler et al. 2004) confirmed the earlier proposal of Dressler (1994) to conserve the genus in its wider concept (Dressler 1994).

D. L. Szlachetko · M. Kolanowska ( $\square)$

Department of Plant Taxonomy and Nature Conservation,

University of Gdańskul, Wita Stwosza 59, 80-308 Gdańsk,

Poland

e-mail: martakolanowska@wp.pl
The general characteristic of Scaphyglottis comes down to the presence of the pseudobulbs arising from the rhizome as well as apices of older pseudobulbs, the resupinate or non-resupinate flowers with free, similar sepals that are commonly wider than the petals and usually, a prominent column-foot.

Of about 150 specific names published under Scaphyglottis, the total of about 60 species are accepted nowadays and novelties within the genus are still being described (Dressler 2002; Dressler 2004).

Most Scaphyglottis species grow epiphytically, however, they are sometimes found on broken branches as semi-terrestrials. The most common habitats of these plants are the humid and wet forests as well as cloud forests (Dressler 2001).

The geographical range of the genus extends from Mexico to Brazil and Bolivia to the south. About $70 \%$ species occur in Costa Rica and Panama (Dressler 2001). On the list of Colombian orchids, Ortiz and Uribe (2007) placed 32 Scaphyglottis taxa, including two species classified by the authors as Reichenbachanthus. Almost all of them, except $S$. aurea (Rchb.f.) Foldats, were found in the lowlands and lower montane regions up to 2,000 $\mathrm{m}$ a.s.l. (Ortiz Valdivieso and Uribe Vélez 2007).

Recent studies on Scaphyglottis conducted in a few Colombian herbaria revealed the existence of a distinctive species which is described here as new. The characteristics and a line-drawing of the novelty are provided together with information about its ecology.

\section{Materials and methods}

Dried herbarium specimens were examined according to the standard procedures. Each sheet studied was 
Fig. 1 Scaphyglottis filifolius Szlach. \& Kolan.: a habit. Scale bar $5 \mathrm{~cm}$; b dorsal sepal; c petal; d lateral sepal; e lip; f gynostemium. Scale bar $2 \mathrm{~mm}$

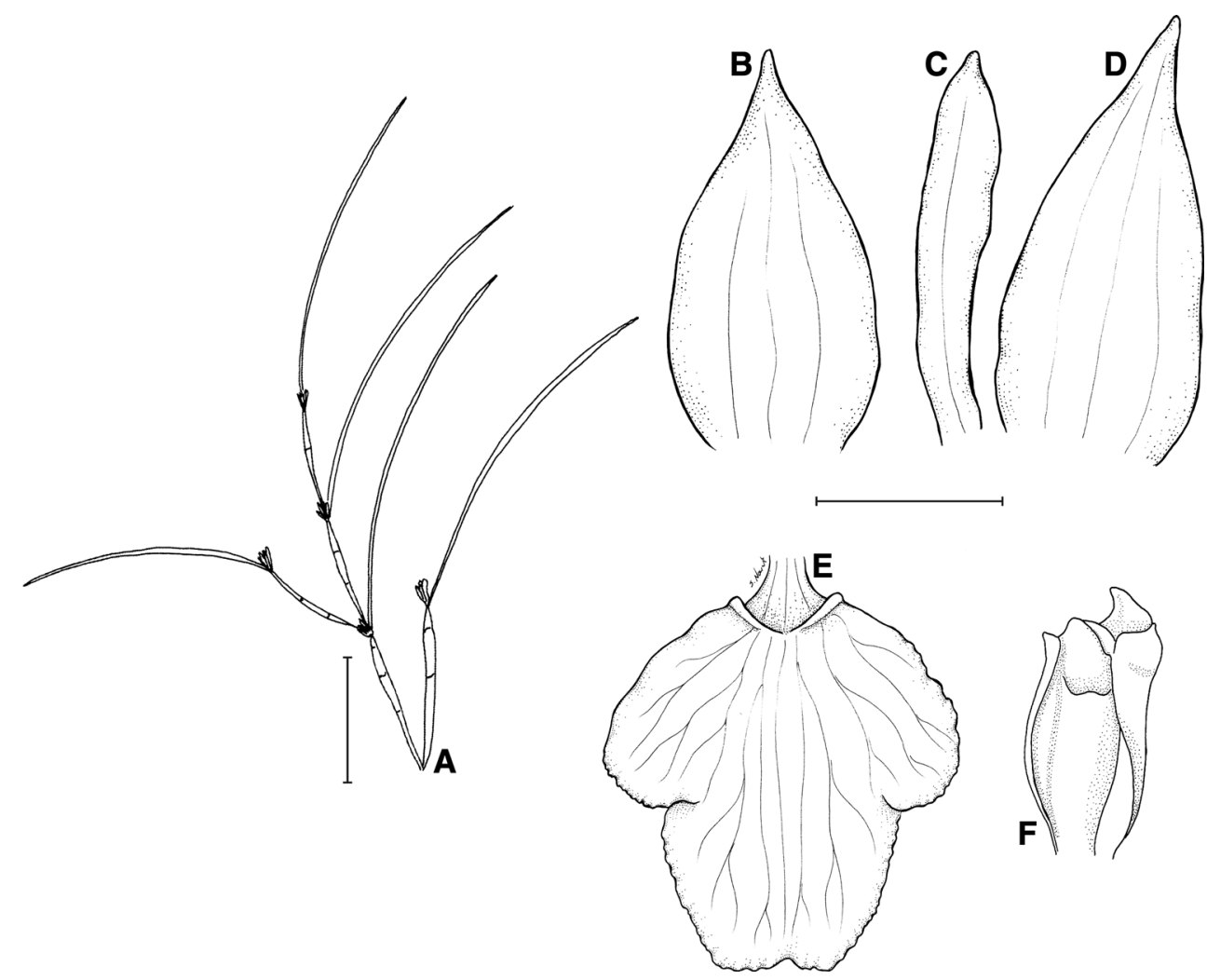

photographed and the data were taken from the labels. Both vegetative and reproductive characters of every plant were studied. The shape and size of the pseudobulbs and leaves were examined first. Then the construction of the inflorescence and the shape and size of the floral bracts were studied. The morphology of the flower, including the gynostemium was examined after being softened in the boiling water. At the end, the measurements on the surface of each floral element were studied under a stereomicroscope.

Acronyms for herbaria cited in this paper follow Index Herbariorum (Thiers 2013, continuously updated). The CorelDraw v.12 software was used for the preparation of the distribution map.

Taxonomic treatment

Scaphyglottis filifolius Szlach. \& Kolan., sp. nov. (Fig. 1)

Plants somewhat similar to Scaphyglottis violacea Lindl., but with 1-leafed pseudobulbs, ovate, acuminate sepals, shortly clawed lip with a prominent, transverse ridge just above the claw, otherwise ecallose.

Type: J.G. Ramírez \& D. Cárdenas L. 1676-Colombia, Antioquia, Mpio. San Luis. Quebrada La Cristalina (25 Sep 1987), (COL!, holotype).

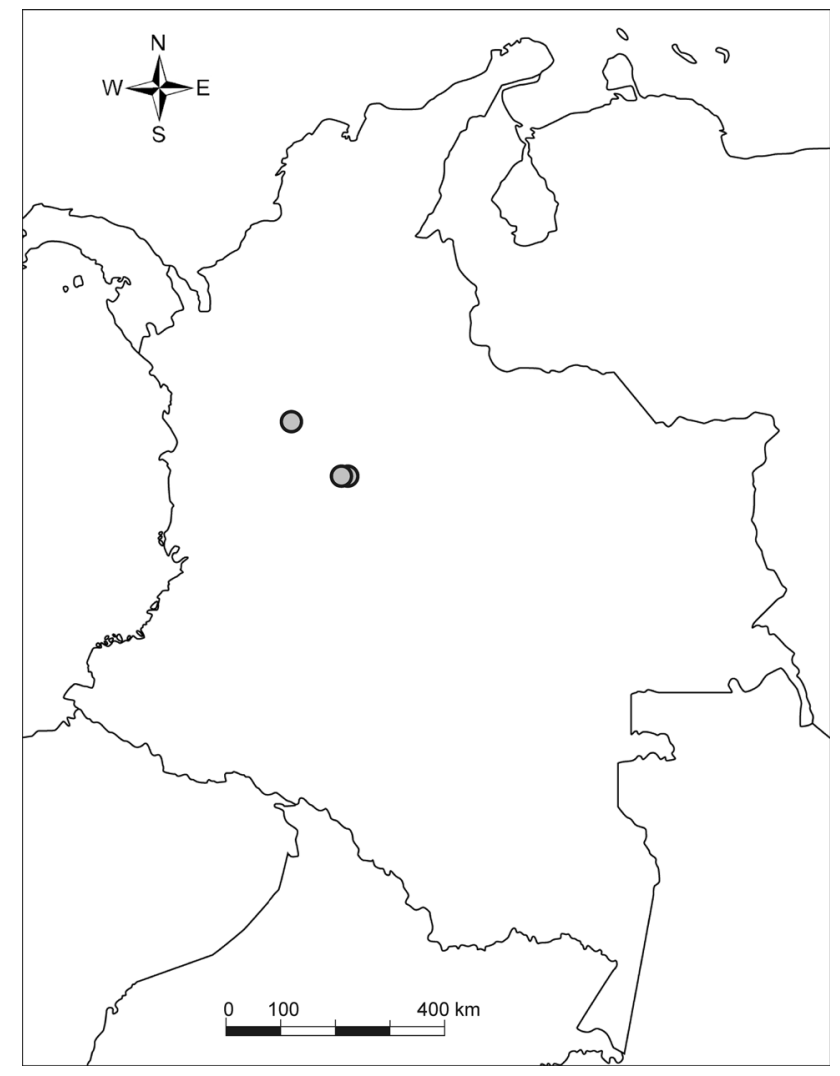

Fig. 2 Distribution of Scaphyglottis filifolius in Colombia 


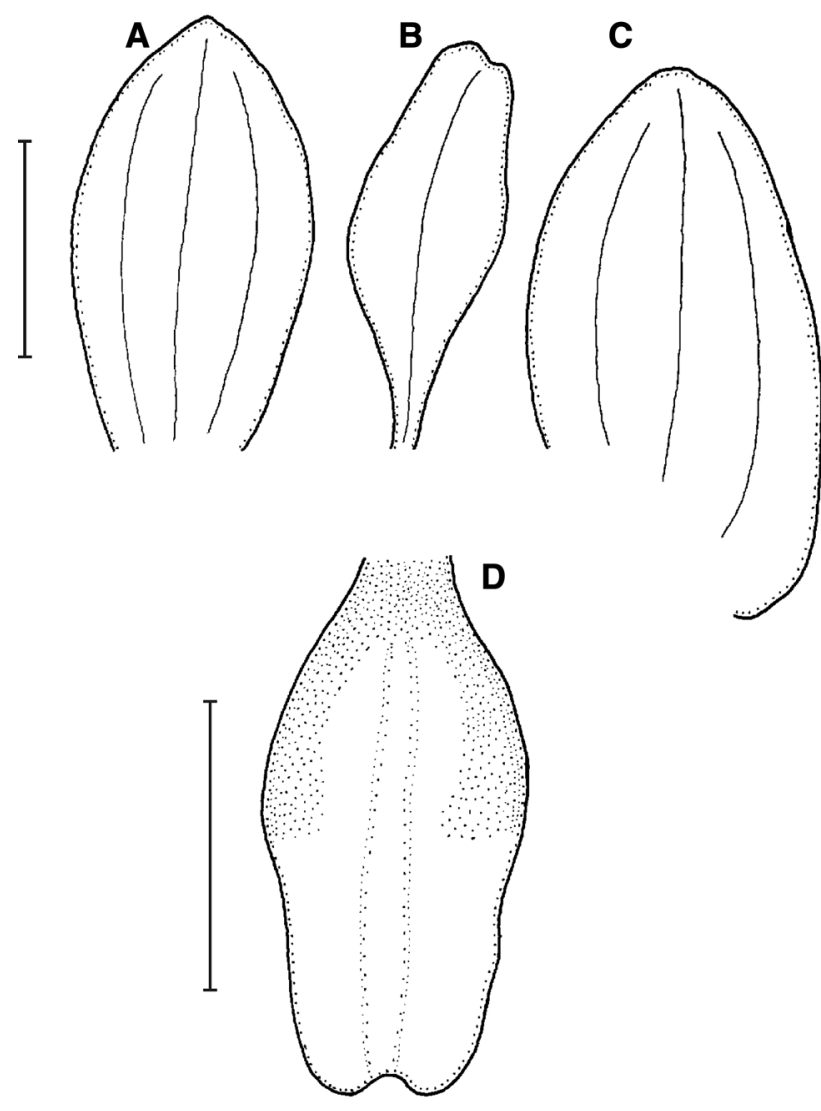

Fig. 3 Scaphyglottis violacea Lindl.: a dorsal sepal; b petal; c lateral sepal; d lip. Scale bars 2.5 mm. Redrawn from Foldats (1970)

Pseudobulbs 5-6 cm long, $0.3 \mathrm{~cm}$ wide, fusiform, unifoliate. Leaf up to $14 \mathrm{~cm}$ long and $0.1 \mathrm{~cm}$ wide, linear, grass-like, acute. Inflorescence fasciculate, with single flower opening in time. Flower small. Floral bracts $5 \mathrm{~mm}$ long. Pedicellate ovary $7 \mathrm{~mm}$ long. Dorsal sepal $4 \mathrm{~mm}$ long, $2 \mathrm{~mm}$ wide, ovate, acuminate, concave in the centre, 3-nerved. Petals up to $4 \mathrm{~mm}$ long and $0.4 \mathrm{~mm}$ wide, linear, somewhat expanded in the upper part, sub-obtuse, subfalcate, 1-nerved. Lateral sepals $4 \mathrm{~mm}$ long, $2.3 \mathrm{~mm}$ wide, somewhat obliquely ovate to oblong-ovate, acuminate, 3-nerved. Lip cuneiform in general outline, shortly clawed; claw 0.3-0.4 mm long, narrow; lamina up to $4.2 \mathrm{~mm} \mathrm{long,}$ $4 \mathrm{~mm}$ wide when spread, distinctly 3-lobed near the middle, at the base of lamina transverse ridge; the middle lobe $2 \mathrm{~mm}$ long and wide, reniform-sub-quadrate, truncate to emarginate; lateral lobes obliquely elliptic, rounded. Gynostemium $3 \mathrm{~mm}$ long.

Etymology: in reference to the exceptionally narrow leaf.

Distribution and ecology: known from Colombian departments of Antioquia and Cundinamarca (Fig. 2) where it was found at the altitudes of about 1,355-1,380 m. Flowering September-December.
Representative material: J.G. Ramirez \& D. Cardenas $L$. 1676-Colombia, Antioquia, Mpio. San Luis. Quebrada La Cristalina (25 Sep 1987), (COL!); A. Chaparro de Barrera \& E. Barrera Torres 294-Colombia, Cundinamarca, Mpio. Caparrapi. Vereda Ocunchi, alt. 1,355 m (8 Dec 1992), (COL!); A. Chaparro de Barrera \& E. Barrera Torres 295Colombia, Cundinamarca, Mpio. La Palma. Finca Senor Caceres, alt. 1,380 m (12 Nov 1992), (COL!).

Taxonomic notes: the new species is characterized by exceptionally narrow, almost filiform leaves, relatively broad sepals, widest near the base and lip having a prominent transverse callus between claw and lamina. The plants are somewhat similar to $S$. violacea widely distributed from Peru to Venezuela, but from this species $S$. $f$ lifolius may be distinguished by the unifoliate pseudobulbs (vs bifoliate in $S$. violacea), ovate, acuminate sepals (vs sepals oblong-oblanceolate to elliptic, obtuse), linear petals (vs petals oblong-oblanceolate) and lip which is ecallose except for the prominent, transverse ridge just above the claw (vs lip disc thickened at the base) (Fig. 3).

\section{Key to the Colombian species of Scaphyglottis}

1. Lip immovable ........ 2

$1 *$ Lip movable......... 3

2. Lateral sepals linear-lanceolate, lip lateral lobes rounded........ Scaphyglottis emarginata

$2 *$ Lateral sepals obliquely oblong-ovate to ovate-lanceolate, lip lateral lobes obtuse-triangular ....... Scaphyglottis reflexa

3. Lip distinctly 3-lobed........... 4

3* Lip entire or obscurely 3-lobed.......... 18

4. Inflorescence a fascicle of 1-2 flowers........ 5

4* Inflorescence a fascicle of more than two flowers........... 13

5. Leaves grass-like, usually less than $0.5 \mathrm{~cm}$ wide ......... 6

$5^{*}$ Leaves linear-lanceolate to elliptic, usually more than $0.5 \mathrm{~cm}$ wide ........ 8

6. Lip middle lobe sub-quadrate....... Scaphyglottis exilis

6* Lip middle lobe sub-triangular........... 7

7. Lip middle lobe acuminate, lateral lobes rounded......... Scaphyglottis chocoana

7* Lip middle lobe acute, lateral lobes obtuse........ Scaphyglottis longicaulis

8. Leaves linear-ligulate, bilobulate at the apex......... 9

8* Leaves lanceolate, acute........ 11

9. Lip middle lobe decurved, sub-quadrate, margins crenulate ..... Scaphyglottis triloba

9* Lip middle lobe not decurved, sub-orbicular-flabellate or sub-quadrate, apex bifid...... 10 
10. Lip middle lobe widest at base, rounded at the apex........... Scaphyglottis bilineata

$10^{*}$ Lip middle lobe widest at the apex, truncate.

Scaphyglottis lueckelii

11. Lateral lobes obliquely sub-quadrate, short...... Scaphyglottis stricta

11* Lateral lobes obliquely obovate, rounded........ 12

12. Lip middle lobe rounded, obtuse............ Scaphyglottis boliviensis

12* Lip middle lobe long acuminate, acute.......... Scaphyglottis huebneri

13. Middle lobe of the lip emarginate, retuse ........ 14

13* Middle lobe of the lip apiculate, acute to obtuse........

Scaphyglottis modesta

14. Lip longer than tepals...... 15

$14^{*}$ Lip sub-equal in length to tepals....... 16

15. Leaves elliptic to oblong-lanceolate ...... Scaphyglottis

bifida

15* Leaves linear-oblong....... Scaphyglottis behrii

16. Leaf about $0.1 \mathrm{~cm}$ wide....... Scaphyglottis filifolius

16* Leaf more than $0.3 \mathrm{~cm}$ wide........ 17

17. Lip 3-3.5 mm long, middle lobe elliptic-obovate..... Scaphyglottis violacea

$17^{*}$ Lip 6-8.5 mm long, middle lobe ligulate to rectangular.......... Scaphyglottis stellata

18. Inflorescence a fascicle of few flowers........ 19

18* Inflorescence 1-2-flowered......... 20

19. Lip about $10 \times 5 \mathrm{~mm}$, sub-pandurate..... Scaphyglottis coriacea

$19 *$ Lip $2.5-4 \times 1.5-2.5 \mathrm{~mm}$, obovate to oblong....... Scaphyglottis minutiflora

20. Leaves oblong-elliptic to eliptic-lanceolate....... 21

$20 *$ Leaves linear............ 23

21 Pedicellate ovary about $20 \mathrm{~mm}$ long, lip panduriformobovate.... Scaphyglottis arctata

21* Pedicellate ovary about 3-4 mm long, lip spathulate........ 22

22. Sepals up to $3.5 \mathrm{~mm}$ long, petals sub-obtuse........ Scaphyglottis sickii

22* Sepals up to $2.5 \mathrm{~mm}$ long, petals emarginate...... Scaphyglottis signata

23. Sepals linear-lanceolate, ligulate to lanceolate......... 24

23* Sepals elliptic-ovate......... 26

24. Lip spthulate to cuneate-flabellate........ 25

24* Lip oblong-ovate.......... Scaphyglottis isochiloides

25. Apical part of the lip obtuse...... Scaphyglottis esuriens

25* Apical part of the lip apical part semi-orbicular.......

Scaphyglottis fusiformis

26. Lip anchoriform........ Scaphyglottis gentryi

26* Lip sub-quadrate, cuneate-ovate, oblong-lanceolate to ovate 27
27. All tepals similar in size and shape....... 28

27* Petals distinguished from sepals....... 31

28. Leaves less than $5 \mathrm{~mm}$ wide ........ Scaphyglottis sessilis

28* Leaves more than $5 \mathrm{~mm}$ wide 29

29. Tepals elliptic to ovate-elliptic .......... Scaphyglottis aurea

29* Tepals lanceolate-oblong to ovate-oblong 30

30 . Stems usually simple, or just with few branches........ Scaphyglottis punctulata

30* Stems branched Scaphyglottis summersii

31. Lip flabellate, cuneate-ovate........ 32

$31 *$ Lip sub-quadrate to ovate-quadrate........ Scaphyglottis livida

32. Pseudobulbs stipitate ........ Scaphyglottis graminifolia 32* Pseudobulbs cylindric-fusiform ....... Scaphyglottis prolifera

Acknowledgments The Curator and staff of the National Colombian Herbarium are thanked for their kind hospitality and assistance during visits and for making specimens available on loan. We are grateful to Sławomir Nowak for preparing the illustration. The research described here has been supported by the Polish Ministry of Science and Higher Education (research grant no. 8124/B/PO1/2011/40).

Open Access This article is distributed under the terms of the Creative Commons Attribution License which permits any use, distribution, and reproduction in any medium, provided the original author(s) and the source are credited.

\section{References}

Adams BR (1988) New species and combinations in the genus Scaphyglottis. Phytologia 64:249-258

Ames O (1937) Orchidaceae. In: Standley PC (ed) Flora of Costa Rica, Part. Field Museum of Natural History, Chicago

Dressler RL (1994) Proposal to conserve Scaphyglottis against Hexisea (Orchidaceae). Taxon 43:665-666

Dressler RL (2001) Scaphyglottis. In: Pridgeon AM, Cribb PJ, Chase MW, Rasmussen FN (eds) Genera Orchidacearum, vol 4: Epidendroideae (Part 1). Oxford University Press, Oxford, pp 310-313

Dressler RL (2002) New species and combinations in Costa Rican Orchids II. Lankesteriana 3:25-29

Dressler RL (2004) Der Scaphyglottis pulchella Komplex; the Scaphyglottis pulchella complex. Journal für den Orchideenfreund 11:305-315

Dressler RL, Whitten M, Williams NH (2004) Phylogenetic relationships of Scaphyglottis and related genera (Laeliinae: Orchidaceae) based on nrDNA ITS sequence data. Brittonia 56:58-66

Foldats E (1970) Scaphyglottis violacea. In: Lasser T (ed) Flora de Venezuela, vol XV. Instituto Botánico, Caracas, pp 110-113

Ortiz Valdivieso P, Uribe Vélez C (2007) Galería de Orquídeas de Colombia (CD edition). Asociación Bogotana de Orquideología, Bogotá

Poeppig EF, Endlicher SL (1836) Nova Genera ac Species Plantarum quas in Regno Chilensi Peruviano et in Terra Amazonica 1:58

Thiers B (continuously updated) Index Herbariorum (2013) A global directory of public herbaria and associated staff. New York Botanical Garden's Virtual Herbarium. http://sweetgum.nybg.org/ih/ 